\title{
Investigasi mekanisme korosi pada pipa pemanas udara di Pabrik Gula Pagotan Madiun
}

\author{
Fahrudin Kurniawan ${ }^{*}$, Wawan Trisnadi Putra ${ }^{2}$, Munaji ${ }^{3}$, Rizal Arifin ${ }^{4}$ \\ 1,2,3,4Program studi Teknik Mesin, Fakultas Teknik, Universitas Muhammadiyah Ponorogo \\ Jl. Budi Utomo No. 10 Ponorogo, 63471 Indonesia \\ ${ }^{*}$ Corresponding author: fahrudinkurniawan5@gmail.com
}

\begin{abstract}
This study aims to determine the inner surface morphology of pipes and to identify pipe corrosion products using stereo microsocope and X-ray diffraction (XRD) observations. In this study, the sample used was a piece of Blacksteel gas pipe that had been used for 107 days and 570 days with dimensions of $3 \mathrm{~cm}$ in length and $4 \mathrm{~cm}$ in diameter. The sample was taken from the Air heater Unit of the Pagotan Madiun sugar factory, East Java, Indonesia. Morphology the inside of the tube was observed with a CARL ZEISS Stemi DV4 stereo microscope (32x magnification). Furthermore, the rust material powder on the sample pipe was taken to determine the corrosion product using the XRD X'Pert PRO instrument. The results of observation by using a stereo microscope on the inner surface of air heater pipe that had been used for 107 days and 570 days indicated that the pipe surface experienced corrosion and peeling. From the results of X-ray diffraction (XRD) observations, $\mathrm{FeOOH}$ layer were formed from $\mathrm{Fe}^{2+}$ and $\mathrm{OH}^{-}$ions produced from $\mathrm{O}_{2}$ and $\mathrm{H}_{2} \mathrm{O}$ molecules in the smoke gas from burning bagasse. At the bottom of $\mathrm{FeOOH}$ layer, $\mathrm{Fe}_{3} \mathrm{O}_{4}$ was formed from the subsequent reaction between $\mathrm{FeOOH}$ and $\mathrm{Fe}^{2+}$ ions.
\end{abstract}

Keywords: pipe, air heater, corrosion, smoke gas.

\begin{abstract}
Abstrak
Penelitian ini bertujuan untuk mengetahui morfologi permukaan dalam pipa dan mengidentifikasi produk korosi pipa menggunakan pengamatan mikrosokop stereo dan X-ray diffraction (XRD). Dalam penelitian ini, sampel yang digunakan berupa potongan pipa Gas Blacksteel bekas pemakaian 107 hari dan 570 hari berdimensi Panjang $3 \mathrm{~cm}$ dan diameter 4 $\mathrm{cm}$. Sampel tersebut diambil dari Unit Air heater pabrik gula Pagotan Madiun, Jawa Timur, Indonesia. Morfologi Bagian dalam pipa tersebut diamati dengan mikroskop stereo CARL ZEISS Stemi DV4 (Perbesaran 32x). Selanjutnya, serbuk material karat pada pipa sampel diambil untuk mengetahui produk korosinya menggunakan instrument XRD X'Pert PRO. Hasil pengamatan menggunakan mikroskop stereo pada bagian permukaan dalam pipa pemanas udara yang telah digunakan selama 107 hari dan 570 hari menunjukkan bahwa permukaan pipa mengalami korosi dan pengelupasan. Dari hasil pengamatan X-ray diffraction (XRD) diperoleh senyawa $\mathrm{FeOOH}$ yang terbentuk dari ion $\mathrm{Fe}^{2+}$ dan $\mathrm{OH}^{-}$yang dihasilkan dari molekul $\mathrm{O}_{2}$ dan $\mathrm{H}_{2} \mathrm{O}$ pada gas asap hasil pembakaran ampas tebu. Di bagian bawah lapisan $\mathrm{FeOOH}$ terbentuk $\mathrm{Fe}_{3} \mathrm{O}_{4}$ dari reaksi lanjutan antara $\mathrm{FeOOH}$ dengan ion $\mathrm{Fe}^{2+}$.
\end{abstract}

Kata kunci: pipa, pemanas udara, korosi, gas asap

\section{Pendahuluan}

Beberapa pabrik gula di Indonesia, termasuk pabrik gula Pagotan, menggunakan bahan blacksteel sebagai pipa saluran pemanas udara. Dengan adanya pipa pemanas, udara dari luar yang akan masuk di ruang bakar boiler mengalami pemanasan untuk menyempurnakan proses pembakaran [1].

Pada umumnya pipa yang sering dialiri fluida sangat rentan mengalami korosi [2]. Umur pipa dipengaruhi adanya 
pitting atau tidak dan jenis korosi yang terbentuk [3]. Adanya unsur kimia bersifat korosif di lingkungan dapat meningkatkan laju korosi yang dampaknya terjadi pengikisan material secara masif [4]. Dari hasil kajian simulasi sebelumnya, ditemukan bahwa interaksi antara oksigen dan air dengan permukaan batang baja secara terus menerus mendorong terbentuknya senyawa $\mathrm{FeOOH}$ atau produk korosi utama [5].

Pengetahuan tentang mekanisme terjadinya korosi pada suatu material industri tertentu pada kondisi ekstrim menjadi sangat penting sebagai rujukan informasi bagi pengguna. Dengan adanya informasi tersebut, pengguna dapat melakukan upaya mengurangi potensi korosi dengan melakukan pelapisan pada permukaan.

\section{Metode Penelitian}

Dalam penelitian ini, sampel yang digunakan berupa potongan pipa Gas Blacksteel bekas pemakaian 107 hari dan 570 hari berdimensi Panjang $3 \mathrm{~cm}$ dan diameter $4 \mathrm{~cm}$. Sampel tersebut diambil dari Unit Air heater pabrik gula Pagotan Madiun, Jawa Timur, Indonesia. Morfologi Bagian dalam pipa tersebut diamati dengan mikroskop stereo CARL ZEISS Stemi DV4 (Perbesaran 32x) di Laboratorium Teknik Metalurgi ITS Surabaya. Selanjutnya, serbuk material karat pada pipa sampel diambil untuk mengetahui produk korosinya menggunakan instrument XRD X'Pert PRO di Laboratorium yang sama.

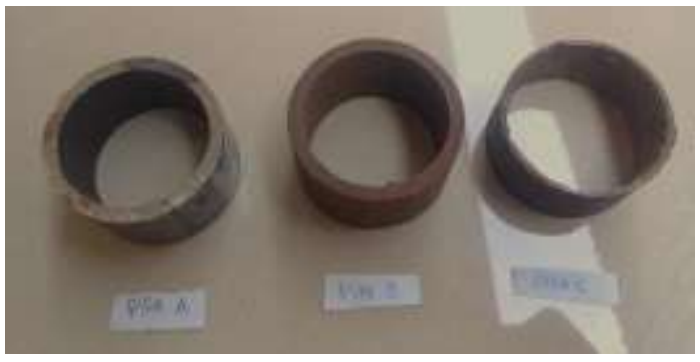

Gambar 1. Pipa A merupakan pipa yang belum digunakan. Sampel penelitian berupa pipa B dan C yang masing-masing merupakan pipa dengan pemakaian 107 hari dan 570 hari.
Tabel 1. Spesifikasi Pipa Air Heater.

\begin{tabular}{ccc}
\hline No. & $\begin{array}{c}\text { Pipa gas black } \\
\text { steel }\end{array}$ & Dimensi \\
\hline & $\begin{array}{c}\text { Diameter luar x } \\
\text { Diameter } \\
\text { dalam x } \\
\text { Ketebalan }\end{array}$ & $\begin{array}{c}48 \mathrm{~mm} \text { x } 40 \mathrm{~mm} \\
\text { x } 4 \mathrm{~mm}\end{array}$ \\
\hline 2 & Panjang & 6000 mm \\
\hline 3 & Aplikasi & Pipa Fluida \\
\hline 4 & Grade & $\begin{array}{c}\text { 12A STKM 12 } \\
\text { A }\end{array}$ \\
\hline 5 & Nuber & A513, A519 \\
\hline 6 & Standart & $\begin{array}{c}\text { DIN 17120 atau } \\
\text { JIS G. 3444 }\end{array}$ \\
\hline
\end{tabular}

\section{Hasil dan Pembahasan}

Untuk mengetahui korosi pada bagian dalam pipa yang telah digunakan selama 107 dan 570 hari, kami tunjukkan hasil pengujian yang diperoleh dari mikroskop stereo pada gambar 2. Dapat dilihat dari gambar 2a bahwa setelah masa penggunaan 107 hari tersebut permukaan pipa mengalami korosi secara merata ditunjukkan pada gambar 2 lingkaran berwarna kuning. Dapat ditemukan juga bahwa beberapa material berkarat telah terkelupas dari logam utama ditunjukkan pada gambar 2 arah panah berwarna kuning. Gambar 2b menunjukkan bahwa setelah pipa digunakan selama 570 hari, korosi menyebar ke seluruh permukaan bagian dalam pipa, ditunjukkan pada gambar 2 lingkaran berwarna kuning. Pengelupasan bahan berkarat yang menyebabkan kerusakan permukaan juga ditemukan lebih serius daripada pipa yang digunakan setelah 107 hari, pengelupasan pipa ditunjukkan pada Gambar 2 arah panah berwarna kuning dan bentuk permukaan menjadi berongga. Produk korosi berupa $\mathrm{Fe}_{3} \mathrm{O}_{4}$, yang biasannya berwarna hitam, dan warna coklat kemerahan ditemukan pada permukaan bagian dalam pipa saluran pemanas udara [6].

Selanjutnya, kami melakukan pengamatan menggunakan XRD pada serbuk karat yang diambil dari pipa $b$ 
dengan masa pemakaian 570 hari untuk mengetahui komposisi zat hasil korosi. Gambar 3 menunjukkan grafik hasil identifikasi senyawa produk korosi menggunakan XRD. Dari hasil tersebut, kami menemukan zat FeOOH (geothite) sebagai produk korosi. Temuan ini konsisten dengan penelitian sebelumnya yang menyatakan bahwa $\mathrm{FeOOH}$ adalah salah satu produk korosi yang dapat ditemukan pada permukaan baja [5].
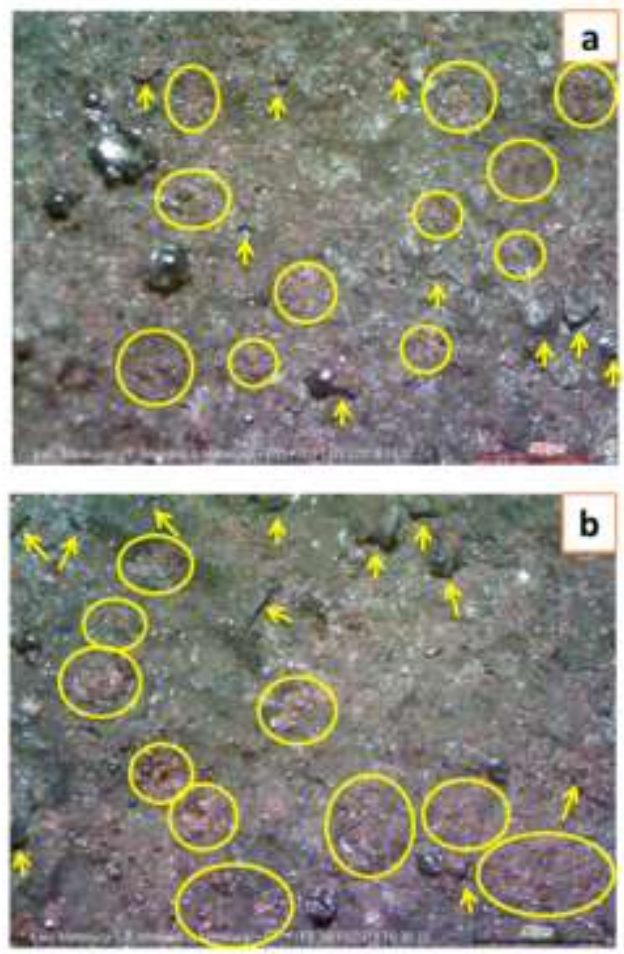

Gambar 2. Hasil pengujian mikroskop stereo dengan perbesaran 32x untuk pipa dengan pemakaian 107 hari (a) dan 570 hari (b). Lingkaran dan anak panah berwarna kuning masing-masing menunjukkan karat dan pengelupasan.

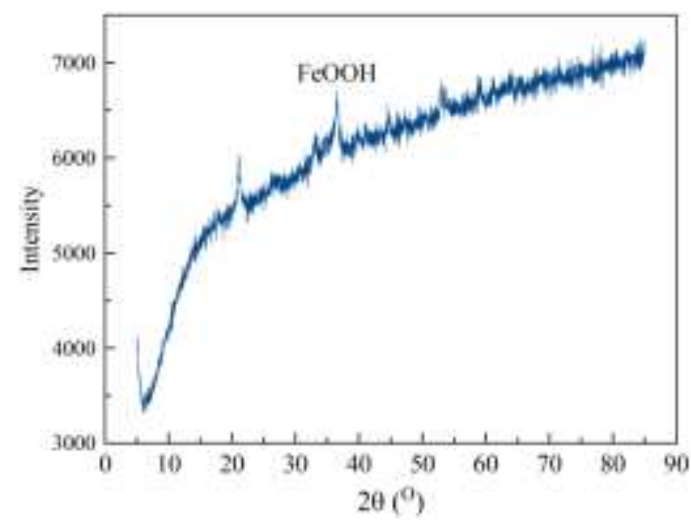

Gambar 3. Grafik hasil identifikasi zat produk korosi pipa menggunakan XRD.
Dari hasil pengamatan produk korosi yang berupa lapisan $\mathrm{FeOOH}$ dan $\mathrm{Fe}_{3} \mathrm{O}_{4}$, kita dapat menentukan mekanisme proses terjadinya korosi sebagaimana yang ditunjukkan Gambar 4 [7][8][9][10][11][12][13].

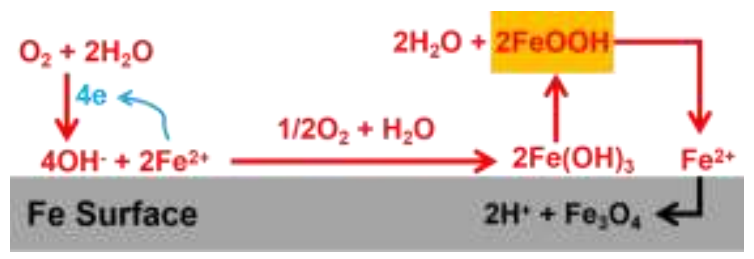

Gambar 4. Mekanisme korosi pada permukaan pipa baja saluran pemanas udara

Proses korosi diawali dengan reaksi di permukaan bagian dalam pipa antara ion $\mathrm{Fe}^{2+}$ dengan $\mathrm{OH}-$ yang dihasilkan dari $\mathrm{O}_{2}$ dan $\mathrm{H}_{2} \mathrm{O}$. Dari hasil reaksi yang pertama terbentuk senyawa $\mathrm{Fe}(\mathrm{OH})_{3}$, dan kemudian terbentuk lapisan $\mathrm{FeOOH}$. Senyawa $\mathrm{FeOOH}$ bereaksi dengan ion $\mathrm{Fe}^{2+} \mathrm{di}$ permukaan logam membentuk $\mathrm{Fe}_{3} \mathrm{O}_{4}$ [13].

Dari hasil pengukuran uji emisi gas asap didapatkan nilai $\mathrm{O}_{2}$ sebesar $14,3 \%$ pada produk korosi dalam pipa pemanas udara [14]. Kemudian hasil unsur kimia $\mathrm{H}_{2} \mathrm{O}$ diperoleh dari pembakaran ampas tebu yang sudah digiling sebagai bahan bakar boiler yang masih ada kandungan airnya sehinggga terjadi penguapan pada ruang bakar boiler yang menghasilkan gas asap.

\section{Kesimpulan}

Dari hasil penelitian yang diperoleh, dapat menyimpulkan bahwa telah terjadi korosi pada permukaan dalam pipa saluran pemanas udara. Karat yang terbentuk akibat korosi telah menyebar merata di seluruh permukaan bagian dalam pipa yang telah digunakan selama 570 hari. Hasil pengamatan juga menunjukkan adanya pengelupasan permukaan pipa akibat korosi. Dari hasil pengamatan XRD, kita menemukan produk korosi $\mathrm{FeOOH}$ yang terbentuk dari reaksi antara besi di permukaan logam dengan ion $\mathrm{OH}^{-}$yang merupakan hasil reaksi antara air sisa dari ampas tebu dan oksigen. Senyawa $\mathrm{Fe}_{3} \mathrm{O}_{4}$ yang juga merupakan hasil korosi terbentuk 
dari reaksi antara $\mathrm{FeOOH}$ dan ion $\mathrm{Fe}^{2+}$ di permukaan pipa.

\section{Ucapan Terima Kasih}

Penulis mengucapkan terima kasih kepada Pabrik Gula Pagotan Madiun sebagai tempat pengambilan data penelitian.

\section{Referensi}

[1] Sudarto. 2011. "Ketel Uap dan Pompa". Yogyakarta. Politeknik LPP Yogyakarta.

[2] Hutauruk, F. Y. 20017. “Analisa Laju Korosi pada Pipa Baja Karbon dan Pipa Galvanis dengan Metode Elektrokimia". Skripsi. Universitas Sanata Dharma Yogyakarta.

[3] Meryanalinda, dan Rustandi, A. 2014. "Perhitungan dan Analisis Laju Korosi dan Sisa Umur Pipa Gas Api 5 L Grade B Menggunakan Standar Asme B . 31 . 8 Dan Api 570 serta Perangkat Lunak Rstreng Pada Pt . X”. Skripsi. Universitas Indonesia.

[4] Kumar, S, M. et al., 2008. "Failure analysis of a stainless steel pipeline". Journal Engineering Failure Analysis. vol. 15, no. 5, pp. 497-504.

[5] Chen, Z. et al., 2020. "A DFT study on corrosion mechanism of steel bar under water-oxygen interaction". Journal Computational Materials Science. vol. 171, pp. 109265.

[6] Pradityo, P. H. 2012. "Analisis Kegagalan Pipa Primary Separator”. Skripsi. Institut Pertanian Bogor.

[7] Cabrera, L. et al., 2008. "Magnetite nanoparticles: Electrochemical synthesis and characterization". Journal Electrochimica Acta .vol. 53, no. 8 , pp. 3436-3441.

[8] Otake, T. et al., 2010. "Mechanisms of iron oxide transformations in hydrothermal systems". Journal Geochimica et Cosmochimica Acta. vol. 74, no. 21, pp. 6141-6156.

[9] Evans, R. U. 1969. "Mechanism of rusting”. Journal Corrosion Science. vol. 9 , no. 11 , pp. 813-821.

[10] Evans, R. U. And Taylor, J. A. C. 1972. "Mechanism of atmospheric rusting". Journal Corrosion Science. vol. 12 , no. 3, pp. 227-246.

[11] Stratmann, M. et al., 1983. "An electrochemical study of phasetransitions in rust layers". Journal Corrosion Science. vol. 23, no. 9, pp. 969-985.

[12] Stratmann, M. and Hoffmann, K. 1989. "In situ Mößbauer spectroscopic study of reactions within rust layers". Journal Corrosion Science. vol. 29, no. 11-12, pp. 1329-1352.

[13] Kim, S. Y. and J. G. Kim, G. J. 2017. "Corrosion behavior of pipeline carbon steel under different iron oxide deposits in the district heating system". Article Metals (Basel),, vol. 7, no. 5 pp 182.

[14] P. G. Pagotan, "Laporan Hasil Pengujian Emisi Boiler Osro No. 2," Madiun, 2019. 